\title{
Research on Local College ESP Testing Mode Based on the Demand Analysis of English Major
}

\author{
Ziqian Luo ${ }^{1, a}$; Dan Zhou ${ }^{2, b, *}$ \\ ${ }^{1}$ Wuhan Huaxia University of Technology, Wuhan, 430223, China \\ ${ }^{2}$ Wuhan Textile University, Wuhan, 430073, China \\ aemail: 13949648@qq.com; bZhoudan@wtu.edu.cn
}

Keywords: Local colleges, ESP testing mode, Demand analysis, English major.

\begin{abstract}
College ESP teaching is inefficient because the lack of a unified ESP test is one of reasons. In order to investigate current situations especially tests and existing problems of English for Specific Purposes (ESP) teaching in local colleges, two local colleges was chosen as objects. College students, teachers and graduates from two colleges are investigated through different methods such as questionnaires and interviews. Under the background of the transfer of college English teaching contents from English for General Purposes (EGP) to ESP, the paper puts forward the following suggestions: adding English for Special Academic Purposes (ESAP) courses, conducting occupational needs analysis and opening a unified ESP test. In this way, pushed by the ESP test, the college ESP teaching might be substantially improved. A $3+\mathrm{N}$ scheme of the unified ESP test is proposed for remedying defects of CET-4 and CET-6.
\end{abstract}

\section{Introduction}

ESP research began in the 1970s in China. Although China's ESP teaching and research have made great progress in both breadth and depth, our ESP teaching and research in college have not made huge breakthrough in theory and practice yet. [1] In general, the objectives of local colleges should be located in the training of applied talents, serving the local or industry economy. In reality, the orientation of research universities and higher vocational colleges is relatively clear, but our local colleges and universities in the middle position is unfit for a higher post but unwilling to take a lower one in choosing development orientation. [2] So they are facing great employment pressure, especially the new-built local colleges and universities. At present, more than 600 local colleges and universities in China will transit to be applied technique-oriented and to be the type of vocational education. [3] The transformation of local colleges and universities has become the focus of the current teaching reform of higher education in China. [4]University ESP teaching is inefficient for many reasons, but the lack of a unified assessment mechanism is one of the important reasons. Any kind of teaching activities should have a certain form of assessment or testing in order to obtain maximum efficiency.

\section{Investigation and Analysis of Colleges}

\subsection{ESP Questionnaire for Students}

\subsubsection{Research Methods of ESP Questionnaire for Students}

In order to investigate the current situation of ESP teaching in local colleges and universities, find the existing problems and put forward solutions, this study chose a technical college, a normal college and a liberal arts college from one province as the research object. Through the questionnaire survey, interviews and lectures, etc. Students and graduates were investigated. The 
main items are research methods, purposes and objects which are shown in Table 1.

Table 1 List of research methods, purposes and objects

\begin{tabular}{|c|c|c|}
\hline Research methods & Research purposes & Research objects \\
\hline $\begin{array}{c}\text { ESP Questionnaire for } \\
\text { Students }\end{array}$ & $\begin{array}{c}\text { To investigate the current } \\
\text { situation of ESP teaching and } \\
\text { testing and find the existing } \\
\text { problems }\end{array}$ & $\begin{array}{c}180 \text { senior students in six } \\
\text { different majors from three } \\
\text { colleges }\end{array}$ \\
\hline $\begin{array}{c}\text { Questionnaire for } \\
\text { Graduates (including } \\
\text { postgraduate in school) }\end{array}$ & $\begin{array}{c}\text { To investigate employers' use } \\
\text { of English and graduates' } \\
\text { views on ESP teaching }\end{array}$ & $\begin{array}{c}30 \text { graduations from } 30 \\
\text { work units in China }\end{array}$ \\
\hline
\end{tabular}

\subsubsection{Results of the ESP Questionnaire}

ESP questionnaire research was conducted in the graduates' class meeting before the final graduation. We chose one class from the major of machinery in technical college, one class from history and chemistry in college of arts and sciences and English and Chinese major in normal college separately to distribute questionnaires. A total of 180 questionnaires were distributed and every 60 questionnaires went to each college, and 165 were identified as valid questionnaires. The questionnaire involves in eight single-choice questions and a short answer. Summary of questions are to write about the recommendations of professional English teaching and advice. The results show that $76 \%$ of the students are dissatisfied with ESP; $87 \%$ reflect the teachers only use reading and translation method; $81 \%$ reflect the teachers in the classroom are without multimedia; and $84 \%$ of the students reflect the teachers give class in Chinese mostly or always. In addition, it was found that in four years, English learning was discontinuous and it was taught in large class or the college even did not open professional English classes and so on.

\subsubsection{Results Analysis of ESP Questionnaire}

Many students reflect that from the fourth semester after completing the Basic English, until the seventh semester to learn ESP, the middle two semesters did not learn any transitional English courses, so the basic knowledge of the Basic English had been forgotten almost. So it is difficult to learn ESP with a high difficulty while the learning is not easy to keep up. And when the students adapted to the course, only more than 30 hours of study class soon ended, so they feel they did not learn anything. Some majors would open ESP class in the fifth semester, and after three semesters without any English courses, the graduates feel English had been forgotten already. The overwhelming majority of the students agreed to compress 32 class hours for Basic English to add academic English courses. When asked if there is a need for a unified university ESP exam, 72\% of students agree that it helps to improve their professional English proficiency while the other 28\% think that is a burden and trouble and it is difficult to pass.

\subsection{Questionnaire for Graduates}

\subsubsection{Research Methods of the ESP Questionnaire for Graduates}

The end product of students' demand is the target language ability, which is the starting point to deepen ESP course and also is the key to success. In order to understand the employer's use of English and the views of graduates on ESP teaching, the contents of the questionnaire include the following aspects: the situation of the employer, English requirements of the employer to staff, professional English usage situation in work, views on ESP teaching and so on. There are 8 single-choice questions and an open-ended question, and the short answer questions require respondents to write their views and suggestions on ESP teaching. The objects were 32 graduates who graduated from school after 1 to 2 years, and their majors in the school were electrical 
communication, international trade and Chinese. All 32 graduates responded by e-mail, and the valid questionnaires were 30 copies. Among them, 22 objects are working graduates and 10 postgraduates.

\subsubsection{Results Analysis of the ESP Questionnaire for Graduates}

The results show that $28 \%$ of the respondents frequently or frequently use English, and most of them are girls and service personnel mainly engaged in foreign-related letters and foreign affairs reception work; 22\% basically do not use English, and they mainly work for construction companies and government; 50\% of them occasionally use English, and the majority of them are male first-line production/technical staff, mainly to read English product equipment description and professional books. In the analysis of the questionnaire, we understand that: in addition to two foreign-related enterprises, other units are not arranged for industry English training. Generally, the candidates are required to pass College English Test Band Four (CET-4). 65\% of the respondents agreed the compression of Basic English to add academic English program. 70\% think a unified university ESP exam is necessary.

\subsubsection{Results Analysis of the ESP Questionnaire for Graduates}

From the research and analysis of the questionnaire, it can be learned that the CET-4 have become one of the necessary conditions for the employing units to recruit staff. In addition to some special companies, the demand for professional English is necessary to some degree though the demand may be different because of the nature of the business. But there is few specialized English training for employees, which highlights the importance of ESP teaching. Most of the respondents believe that English learned during school can only meet the basic needs of the future work, so they are not satisfied with the present ESP teaching. The vast majority of respondents suggested that English teaching should focus on the development of practical ability, especially listening and speaking skills and professional reading and focus on cultivating interest in learning and mobilize the enthusiasm of learning.

\subsection{Suggestions for ESP Teaching}

Although more and more attention is given to ESP teaching in language field nowadays, Suggestions as the orientation of national college English teaching still does not give a clear direction to ESP, which has undoubtedly negative effect to college English teaching. Professional teachers should learn English teaching especially ESP teaching theory, and based on the employment situation of students' major, English teachers should strengthen the analysis of the needs of special academic English so as to adjust the ESP teaching content. [5]As an extension of English learning after the completion of the basic stage of teaching, English for EGAP plays a role as a bridge in connecting EGP and English for ESAP. Students should not only just learn English, more importantly, through academic English they are supposed to master international academic norms and methods as well as scientific and innovative ways of thinking, such as logical thinking, critical thinking and comparative thinking. [6]The addition of academic English courses is in line with the needs of the reform and development of college English teaching in local colleges. The academic English class can be used as a transitional course to buffer the difficulty of professional English. It can also make sure the four-year English learning continuous and develop new areas of teaching and research for teachers teaching general Basic English. The specific recommendations are: under the premise of not adding class hours, in the first four semesters, eight Basic English classes can be compressed to make up 32 hours in the fifth semester by the English teacher to teach academic English, which can pave the way for the follow-up ESAP. Besides, the education authorities are urged to pay attention to ESP teaching with a correct top-level design, the addition of academic English courses and the introduction of unified university ESP examinations to test and promote education, in order to truly improve the quality of ESP teaching. 


\section{Exploration for College ESP Test}

College English test has become one of the necessary requirements for social employment unit to employ college graduates, resulting in certain social benefits. But with the development of the situation, the drawbacks of the CET-4 or CET-6 began to appear. [7] In this context, to make up for these defects, the addition of a university ESP exam which is at the same level of CET exam can adapt to the development of the situation as the effective complement. But for many reasons, until today there is no national university ESP exam, and I try to propose an immature $3+\mathrm{N}$ program from the perspective of testing content. The program is as follows:

College English ESP papers can be composed of independent two parts: academic English papers and specialized English papers, each of which takes up half scores. Based on the dichotomy of Hutchinson \& Waters (1987), ESP can be divided into three categories from the perspective of subject categories: English for Science and Technology (EST), English for Business and Economics (EBE) and English for Social Science (ESS). These three categories cover almost all the disciplines of the university. Students choose one of the three categories according to their majors. The exam mainly tests students' academic listening, academic reading and academic writing. Specialized English papers are divided into different types according to different majors, that is to say there are diverse types of papers, and students according to their own majors to participate in the corresponding specialized English test. On the basis of industry demand analysis, the exam mainly tests students' professional reading and professional translation.

\section{Conclusion}

Examination is not the purpose. It is only a means to improve the quality of teaching. But if there is no authoritative and unified examination, teaching efficiency and quality in the community is difficult to be widely recognized, and social and economic benefits are also difficult to obtain long-term protection. CET-4 and CET-6 are good examples. The establishment of a unified national college English ESP exam will involve a large number of disciplines and different industry needs, the difficulty can be imagined. But once completed, it will be certainly like the original CET-4 and CET-6 examinations, causing local colleges and relevant government departments to notice the importance of ESP teaching, mobilizing the enthusiasm of teachers and students and thus improving the current efficiency and quality of ESP teaching that is very low currently, which can contribute to national economic and social development.

\section{Acknowledgements}

In this paper, the research was sponsored by the educational program in Hubei (project number: 2016GB036)

\section{References}

[1] English communicative events and skills needed at the workplace: Feedback from the industry[J] . Hafizoah Kassim,Fatimah Ali. English for Specific Purposes . 2009 (3)

[2] From needs analysis to curriculum development[J].Susan Bosher,Kari Smalkoski. English for Specific Purposes. 2001 (1)

[3] Oral communication: the workplace needs and uses of business graduate employees[J] . Glenda Crosling,Ian Ward. English for Specific Purposes. 2001 (1)

[4] Communicative Syllabus Design:A Sociolinguistic Model forDesigning the Content of Purpose-Specific Language Programmes. Munby John. . 1978

[5] English for Specific Purposes. Hutchinson Tom,Waters Alan. . 2002 
[6] Needs assessment. Kaufman, R,English, F. W. . 1979

[7] English for Specific Purposes: A case study approach. . 1978 